\title{
Analysis of Welfare Effects of South Asia Free Trade Agreement (SAFTA) on Pakistan's Economy by Using CGE Model
}

\author{
Dr. Imamuddin Khoso \\ Assistant Professor \\ IBA-University of Sindh, Jamshoro, Pakistan \\ Dr. Nanik Ram \\ Assistant Professor \\ Department of Economics, University of Sindh, Jamshoro, Pakistan \\ Asif Ali Shah \\ Assistant Professor \\ Department of Commerce \\ Shah Abdul Latif University-Khairpur, Pakistan \\ Kamran Shafiq \\ COMSATS-Abbott bad, Pakistan \\ E-mail: kamranhashmi@ciit.net.pk \\ Faiz. M. Shaikh \\ Assistat Professor \\ SZABAC-Dokri-Khairpur, Sindh, Pakistan \\ E-mail: faizmuhammed_2000@yahoo.com
}

\begin{abstract}
The current research investigates the Welfare impact of SAFTA on the economy of Pakistan in general and South Asia in perspective. This research analyzes the potential economic costs and benefits of Pak-India trade in exporting various consumer goods. The first scenario is when normal trading relation with India will be restored; it means that both countries will give the MFN (Most Favored Nations) status to each other. In the second scenario, the SAFTA will be operative and there will be free trade between India and Pakistan and both countries will remove all tariffs and custom duties from each others' imports. The Global trade analysis GTAP model is used to analyze the possible impact of SAFTA on Pakistan in a multi country, multi sector applied General equilibrium frame work. After employing the simplified static analysis framework, the analysis based on simulations reveals that current demand for Pakistani Basmati Rice and other consumer items like leather and cotton-made garments will expand after the FTA and consumer surplus will increase. The drop in the domestic prices of Rice will increase the production of many downstream industries, which will have pleasant multiplier effects on the economy of Pakistan. The government may reduce MFN tariffs on industrial dates before implementing the FTA. A key rule of multilateral trade system is that the reduction in trade barriers should be applied on a most-favored nation basis (MFN) to all WTO members the countries which are part of the SAFTA.. The only exception to the MFN principle built into the GATT legal framework is the provision for reciprocal free trade within customs unions and free trade areas (GATT article XXIV). The objectives of the present study are to analyze and quantify the potential economic cost and benefits of the prospective trade between India and Pakistan to consumers, producers and government of the two countries. The export of Rice, leather and cotton-made garments may be conducted by two scenarios, i.e. when normal trading relations between Pakistan and India will be restored and when there will be a free trade between Pakistan and India in the presence of
\end{abstract}


South Asian Free Trade Agreement (SAFTA). Results based on this research reveal that on SAFTA, grounds, there will be net export benefits in Pakistan's economy.

Keywords: Agriculture, Trade liberalization, FTA, SAFTA, Welfare gain, Economy

\section{Introduction}

The objective of this study is to present a quantitative assessment of trade liberalization exercises in Pakistan in terms of economic trade, with other south Asian countries. This paper begins with a review of Pakistan's economic reforms and their coverage. Section II discusses the methodology, offering a brief description of CGE Modeling including the GTAP. The experimental designs are discussed in Sections III. Apart from unilateral and regional trade liberalization, as a founding member of the WTO, Pakistan remained firmly committed to the multilateral trading system and has already established a large number of reforms in keeping with the GATT/WTO principles. However, the paper does not review the outcome of multilateral trade Liberalization. In Section IV, GTAP model simulation results are analyzed. Section V concludes.4 Section I Until the late 1970s, Pakistan's economic development centered on an inward-oriented development strategy based on import substitution industrialization performed mainly by state owned firms. Both tariff and non-tariff barriers were widely used to protect domestic economic activities. Trade restrictive policies were accompanied by other regulatory policies such as control on foreign exchange, finance and foreign direct investment. These restrictive economic policies had severe adverse implications on overall economic growth, in particular growth of exports. The agreement on SAFTA was signed in Dhaka in April 1993 by the SAAC members, providing a legal framework for trade liberalization and strengthening intra-regional economic cooperation. In 1995, SAFTA had been ratified by all contracting states and in accordance with Article 22 of the agreement SAFTA became operational on 7th December 1995. SAFTA followed a positive list approach, including flexible provisions for least developed countries (LDCs). At the Ninth SAARC Summit held in Male in 1997, the Heads of Governments decided to accelerate the pace of transition of SAFTA to South Asian Free Trade Agreement (SAFTA) by the year 2001 or Consumption is also quite high during Christmas. Similarly, the fruit enjoys enormous significance on the occasion of Dial and such festivals another religion. In Europe and North America, the fruit is particularly preferred during the dark winter month. Usual sales of dates are spread to a period from October to April.

\section{Methodology}

It is widely acknowledged that applied general equilibrium (AGE) or computable general

Equilibrium (CGE) modeling has become the tool of choice for analysis of a wide range of trade policy issues such as tariffs and non-tariff barriers (NTBs) in both developed and developing countries in a variety of settings. In particular, AGE modeling is useful for analyzing the welfare effect of trade policy that needs to address second-best issues, where there are significant interactions between policy measures for one sector and distortions elsewhere in the economy. Such models have two distinctive features: they incorporate a number of distinct sectors, and the behavioral equations of the model deal with the response of industries and consumers to changes in relative prices (Adams et al., 1998). This development is explained by the capability of CGE models to provide an elaborate and realistic representation of the economy, including the linkages between all agents, sectors and other economies (Brockmeier, 1996) AGE analysis also provides a valuable tool for putting things in an economy-wide perspective (Hertel, 1999). The general equilibrium framework contains all commodities, factor markets together with decision-making agents who respond to price signals and are internally consistent 7 through capturing the many important feedback effects. Therefore, conceptually, these models can explicitly capture all the economy-wide interactions and inter-sectoral linkages. Hence, these models are very useful for analyzing the changes in sectoral output, product prices, factor usage, and factor prices as well as changes in national welfare measures consequent to changes in trade regimes. CGE evaluations typically work with theoretical models, and allow for more interaction among endogenous variables in that they can capture the numerous complex relationships between variables of policy interest in the model economy.

\section{Sensitivity Analysis}

Sensitivity analysis for AGE models is critical for establishing the robustness and obtaining the acceptance of model results. Although AGE models have become important tools of analysis in the quantitative evaluation of trade policy, the solutions obtained from these models are conditional on many assumptions. Among many assumptions, one set of assumptions-the values of model parameters such as elasticities-are amenable to "sensitivity analysis." Evaluation of the robustness of the model results can also help to increase the credibility of the conclusions of the study. In the GTAP model, the substitutability among imported commodities from different sources is determined by the Armington elasticity of substitution parameter called ESUBM. According 
to the Armington assumption, each country has some degree of market power over its products and can influence its terms of trade because that goods from different sources are treated as imperfect 19 substitutes. Hence, to reduce Pakistan's market power, it is necessary to increase the substitutability among imports from different origins because the terms trade effects largely depend on the import-import substitution elasticities (McDougall et al., 1998). This kind of experiment could also be interpreted as a form of conditional systematic sensitivity analysis (CSSA). Under the CSSA; each parameter is separately perturbed from its central value conditional on all the other parameters remaining at their central values. The robustness of the model results is then revealed by comparison of the simulation results with the central case. Thus, three additional experiments are undertaken under the sensitivity analysis to reduced Pakistan's market power by increasing the values of ESUBM to capture the effect of possibly different adjustment capacities as a small country. Though this will affect all countries/regions' market power in the model, it will have most effect on the small countries like Pakistan. The first experiment under the sensitivity analysis (Experiment 4) deals with the unilateral trade liberalization scenario. (15 percent uniform import tariff). The second experiment (Experiment 5) related to the regional trade liberalization (SAFTA by itself) and the third one (Experiment 6) conducted under the unilateral trade liberalization with combination of regional trade liberalization (SAFTA cum 15 percent uniform import tariff). To make these experiments manageable, two separate experiments are conducted under the Experiments 4, 5 and 6 respectively. Thus, under the first experiment, the parameter ESUBM was perturbed from its central value and then increased its value by 50 per cent in the first three scenarios-Experiments 4-1, 5-1 and 6-1 respectively. Under the second experiment, the value of ESUBM was doubled (100 percent increase) for the other three scenarios-Experiments 4-2, 5-2, and 6-2 respectively. With these six scenarios, it was assumed that all other parameters (except ESUBM) in the model remain at their central values.

\section{Simulation Results}

\section{Experiment-1: Reduction of Import Tariffs to 15 percent}

The first experiment considered the Pakistan's reduction of import tariffs to 15 percent under the unilateral trade liberalization. The impact of this scenario on regional welfare and the resulting percentage changes in sectoral output and trade are reported in Table 9 and 10 respectively. Accordingly, if Pakistan (LKA) reduces its import tariffs to 15 percent unilaterally on a global basis to maintain a uniform external tariff rate, Pakistan experiences a welfare gain around US\$20 201 million (1.53 percent of the GDP). Under this scenario, Pakistan's volume of imports rises by 3.3 percent while its volume of exports falls slightly by 0.3 percent reflecting the fact that the pressure to increase imports is stronger than the increase in demand for Pakistan's exports by unilateral liberalization. However, as a result of the composite export price increase by 1.1 percent, Pakistan experiences a small improvement in the terms-of-trade of 1.5 percent and the real GDP by 0.8 percent. The welfare gains or losses for other regions are quite varied under this simulation. However, since Pakistan is a small country, the impact of Pakistan's unilateral reduction of import tariffs to 15 percent will not affect other region's real GDP or terms-of-trade significantly. As shown in Table 9, the 15 percent uniform tariff will adversely affect most of the sectoral output in Pakistan because of the increased competition for import competing industries. As shown in panel (a) of Table 9, the most affected industry is the transport equipment (TREQ) sector (18 percent), followed by machinery and equipment (MAEQ) sector (16 percent). It is noteworthy that these sectors expand significantly under the regional liberalization scenarios, particularly under the SAFTA scenario. The textiles (TEXT) sector ( 8 percent), processed food (PROF) sector ( 8 percent), mining and quarrying (MINQ) sector ( 8 percent), other manufactures (OTHM) sector (5 percent), and agriculture (AGRI) sector (1 percent) also report a decrease in output. However, there is a considerable increase in the wearing apparel (WEAP) sector (21 percent) and marginal increases in both the petroleum and coal products (PECP) sectors (2 percent), and the services (SERC) sector (1 percent). Similarly, as can be seen from panel (b) of Table 9, export sales also decline considerably in almost all the sectors except petroleum products (25 percent) and wearing apparel (21 percent). The largest decline in export sales occurs in machinery and equipment (22 percent) followed by transport equipment (19 percent), processed food (16 percent) and services (15 percent). As shown in panel (c) of Table 9 , Pakistan's sectoral imports expand mainly in processed food (26 21 percent), wearing apparel (20 percent), and textiles (19 percent) while imports contract mainly in agriculture ( 9 percent), services ( 7 percent) and petroleum products (5 percent) under this policy reform. Accordingly, the results suggest that a reduction of import tariffs to 15 percent will increase Sri Lanka's welfare and terms-of-trade as well. Although one might expect that the reduction of import tariffs would increase the domestic output and therefore increase export sales, this policy reform would adversely affect Pakistan's domestic output in most of the sectors because of foreign competition. A similar impact can be seen in export sales too. 


\section{Conclusions}

The regional Block trade is gaining importance in the World. The simulation results presented and analyzed here demonstrate the importance of experimental designs, and the usefulness of the global CGE modeling framework for examining the impacts of the different types of trade policy reforms for Pakistan. Although, the GTAP model cannot capture the dynamic effects of trade liberalization, it is a useful tool for generating comparative static results for a variety of trade reform scenarios. It also identifies the industries that will expand, and those that will contract, and the size of these changes as a result of various trade liberalization scenarios. The results suggest that Pakistan would experience the highest welfare gain under the combined policy reform of the SAFTA cum 15 percent uniform external tariffs while the SAFTA on its own gives the second highest welfare gains. SAFTA allows the participating countries to achieve larger economies of scale in production, attain specialization, increase competitiveness and diversify their export basket, thus assisting domestic economic reform. Therefore, harmonizing economic policies among neighboring countries must receive higher priority in the policy making process. Although, simulation results are highly sensitive to the underlying data and assumptions regarding the reference scenarios, the results clearly provide an assessment of the implications of SAFTA.

\section{References}

Adams. P., K.Huff, R. MacDougall, K. Pearson and A. Powell. (1997). Medium and long run consequences for Australian of an APEC Free Trade Area: CGE Analysis Using the GTAP and Monash modes. Asian Pacific Economic Review, Vol.3 (1): 19-42.

Baldwin, R.E. (1993). A Domino theory Regionalism. NBER WP 4465, Cambridge.

Bhagwati, J. (2002). Free Trade today. Cambridge: MIT press.

Brockmierer, M, M. (1996). A Graphical Exposition of the GTAP model. GTAP technical paper No.8, (with minor edits 2002) Purdue University, [Online] Available: www.agecon.purdue.edu/gtap/techpapr.

Cameron, A. C. and P. K. Trivedi. (1986). Econometric Models Based on Count Data: Comparisons and Applications of Some Estimators and Tests. Journal of Applied Econometrics, 1(1): 29-53.

CBI. (2002). Cut-flowers and foliage. EU Market Survey 2002. Centre of Promotion of Imports from Developing Countries.

Dean, C. B. (1992). Testing for Over dispersion in Poisson and Binomial Regression Models. Journal of the American Statistical Association, 87(418): 451-457.

Frey, J. E. (1993). The analysis of arthropod pest movement through trade in ornamental plants. Pages. 157-165 in D. Ebbels, editor. Plant Health and the European Single Market. British Crop Protection Council, Farnham.

Hertel, T.W. (ed.) (1997). Global Trade Analysis Modeling and Applications. New York: Cambridge University Press.

McDougall, R.A. (1995). Computable General Equilibrium Modeling: Introduction and overview. Asian Pacific Review, Vol. 1 (1): 88-91.

McKitrick, R.R. (1998). The Econometric Critique of Computable General Equilibrium Modeling: The role of functional forms. Economic Modeling, Vol. 15:543-573.

Panagariya, A. (1994). East Asia and the New Regionalism. World Economy, 17:6, 817-39.

Pursell, Garry. (2004a). Analyzing the Economic Welfare Consequences of a Fare Trade Agreement: Partial Equilibrium Methods for Industry Level Studies. Manuscript Presented at World bank Dhaka Office.

Pursell, Garry. (2004b). An India-Bangladesh Free Trade Agreement? Some Potential Economic Costs and benefits, presented during the workshop held at World Bank, Islamabad Office.

Schiff, M. (1996). Small is beautiful Preferential Trade Agreement and the impact of country size, Market share, Efficiency, and Trade policy. Policy Research Working Paper 1668, The World Bank, Washington D.C.

Scollay, R. and J. Gilbert. (1999). CGE Assessment of the Gain from APEC Trade liberalization: A survey and some New Results. Mimeo, APEC Study Centre of New Zealand.

Shoven, J.B. and J. Whalley. (1992). Applied General Equilibrium. New York: Cambridge University Press.

Summers, L. (1991). Regionalism and the World Trading Systems, Federal Reserve Bank of Kansas City. Policy Implementation of Trade and currency zones. 
Thoen, R., Jaffee, S., Dolan, C., and Ba, F. (1999). Equatorial rose: the Kenyan-European cut-flower supply chain. In: Supply chain development in emerging countries: Case studies of supportive public policy, R. Kopic (ed.). MIT Press.

Work, T. T., McCullough, D. G., Cavey, J. F. and Komsa, R. (2005). Arrival rate of no indigenous insect species into the United States through foreign trade. Biological Invasions, 7, 323-332.

Table 1. Key Economic Indicators data for SAARC countries-2005-06

\begin{tabular}{|l|l|l|l|l|l|l|l|l|l|l|}
\hline Country & $\begin{array}{l}\text { Mid Year } \\
\text { Population }\end{array}$ & $\begin{array}{l}\text { Population } \\
\text { in Growth } \\
\text { rate }\end{array}$ & $\begin{array}{l}\text { GDP } \\
\text { US\$ Mn }\end{array}$ & $\begin{array}{l}\text { GNP } \\
\text { Per } \\
\text { capita } \\
\text { US\$ }\end{array}$ & $\begin{array}{l}\text { Literacy } \\
\text { rate }\end{array}$ & $\begin{array}{l}\text { Life } \\
\text { expectancy }\end{array}$ & $\begin{array}{l}\text { Crude } \\
\text { birth } \\
\text { rate } \\
\text { per(000) }\end{array}$ & $\begin{array}{l}\text { Crude } \\
\text { death } \\
\text { rate } \\
\text { exports }\end{array}$ & $\begin{array}{l}\text { Exports } \\
\text { US\$ Mn }\end{array}$ & $\begin{array}{l}\text { Imports } \\
\text { US\$ }\end{array}$ \\
\hline Pakistan & 148.8 & 1.92 & 93,908 & 600 & 48.7 & 63 & 36 & 36 & 13,375 & 17,954 \\
\hline Bhutan & 0.8 & 2.5 & 657 & 760 & 47.0 & 63 & 35 & 9 & n.a & n.a \\
\hline Bangladesh & 135.2 & 1.3 & 585,68 & 440 & 41.1 & 63 & 29 & 8 & 6,608 & 11,276 \\
\hline India & $1,086.0$ & 1.6 & 686,08 & 620 & 61.0 & 63 & 24 & 8 & 71,763 & 94051 \\
\hline Maldev & 0.3 & 1.5 & 719 & 24,10 & 97.2 & 67 & 36 & 6 & 122 & \\
\hline Nepal & 24.7 & 2.2 & 6,685 & 250 & 48.6 & 62 & 33 & 10 & 756 & 1,869 \\
\hline Sri lanaka & 19.5 & 1.1 & 19,224 & 1,010 & 92.1 & 74 & 16 & 7 & 5,757 & 8000 \\
\hline
\end{tabular}

Note: ADB key economic indicators -2005-06

Table 2. Gross National Product of Pakistan

Rs.Million

\begin{tabular}{|l|l|l|l|l|l|l|l|l|l|}
\hline S.No & Sectors/Sub-sectors & $\mathbf{1 9 9 9 - 0 0}$ & $\mathbf{2 0 0 0 - 0 1}$ & $\mathbf{2 0 0 1 - 2 0 0 2}$ & $\mathbf{2 0 0 2 - 0 3}$ & $\mathbf{2 0 0 3 - 0 4}$ & $\mathbf{2 0 0 4 - 0 5}$ & $\mathbf{2 0 0 5 - 0 6}$ & $\mathbf{2 0 0 6 - 0 7}$ \\
\hline A. & Agricultural sector & $\mathbf{9 2 3 6 0 9}$ & $\mathbf{9 4 5 3 0 1}$ & $\mathbf{9 6 8 2 9 1}$ & $\mathbf{1 0 5 9 3 1 6}$ & $\mathbf{1 1 6 4 7 5 1}$ & $\mathbf{1 3 1 4 2 3 4}$ & $\mathbf{1 3 8 2 6 6 0}$ & $\mathbf{1 6 0 8 5 2 2}$ \\
\hline & $\mathbf{1 . C r o p s}$ & 467879 & 456258 & 449993 & 500370117 & 538208 & 651774 & 666727 & 1608522 \\
& $\begin{array}{l}\text { 1.1.Major crops } \\
\text { 1.2.Minor crops }\end{array}$ & 342200 & 325579 & 316857 & 370117 & 411836 & 497556 & 496841 & 579996 \\
& $\begin{array}{l}\text { 2.Livestock } \\
\text { 3.Fishries }\end{array}$ & 417679 & 130679 & 133136 & 130450 & 126372 & 154218 & 169886 & 191835 \\
& 4. Forestry & 44163 & 16546 & 16377 & 16625 & 16728 & 17490 & 22230 & 243559 \\
\hline B. & Industrial Sector & $\mathbf{8 3 0 8 6 5}$ & $\mathbf{9 4 2 2 6 3}$ & $\mathbf{9 8 9 3 4 9}$ & $\mathbf{1 0 8 3 9 1 4}$ & $\mathbf{1 4 1 6 9 8 6}$ & $\mathbf{1 6 5 9 2 8 5}$ & $\mathbf{1 9 3 9 1 6 0}$ & $\mathbf{2 2 0 3 4 9 0}$ \\
\hline A+B & $\begin{array}{l}\text { Commodity } \\
\text { producing Sectors }\end{array}$ & $\mathbf{1 7 5 4 4 7 4}$ & $\mathbf{1 8 8 7 5 6 4}$ & $\mathbf{1 9 5 7 6 4 0}$ & $\mathbf{2 1 4 3 2 3 0}$ & $\mathbf{2 5 8 1 7 3 7}$ & $\mathbf{2 9 7 3 5 1 9}$ & $\mathbf{3 3 2 1 8 2 0}$ & $\mathbf{3 8 1 2 0 1 2}$ \\
\hline C & Services Sector & $\mathbf{1 8 0 7 5 4 6}$ & $\mathbf{2 0 3 5 6 8 0}$ & $\mathbf{2 1 8 8 5 2 7}$ & $\mathbf{2 3 9 0 9 8 8}$ & $\mathbf{2 6 6 8 7 9 0}$ & $\mathbf{3 1 4 9 0 4 9}$ & $\mathbf{3 8 0 7 3 5 6}$ & $\mathbf{4 4 1 4 5 0 7}$ \\
\hline D & $\begin{array}{l}\text { Gross Domestic } \\
\text { Product (GDP) }\end{array}$ & $\mathbf{3 5 6 2 0 2 0}$ & $\mathbf{3 9 2 3 2 4 4}$ & $\mathbf{4 1 4 6 1 6 7}$ & $\mathbf{4 5 3 4 2 1 8}$ & $\mathbf{5 2 5 0 5 2 7}$ & $\mathbf{6 1 2 2 5 6 8}$ & $\mathbf{7 1 2 9 1 7 6}$ & $\mathbf{8 2 2 6 5 1 9}$ \\
\hline E. & $\begin{array}{l}\text { Net Factor Income } \\
\text { from Abroad }\end{array}$ & $\mathbf{4 7 9 5 6}$ & $\mathbf{- 5 4 4 8 2}$ & $\mathbf{2 3 6 6 5}$ & $\mathbf{1 5 1 8 1 2}$ & $\mathbf{1 2 4 4 7 8}$ & $\mathbf{1 3 4 4 6 1}$ & $\mathbf{1 4 9 9 0 1}$ & $\mathbf{1 6 0 7 3 8}$ \\
\hline F. & $\begin{array}{l}\text { Gross National } \\
\text { Product(GNP) }\end{array}$ & $\mathbf{3 5 1 4 0 6 4}$ & $\mathbf{3 8 6 8 7 6 2}$ & $\mathbf{4 1 6 9 8 3 2}$ & $\mathbf{4 6 8 6 0 3 0}$ & $\mathbf{5 3 7 5 0 0 5}$ & $\mathbf{6 2 5 7 0 2 9}$ & $\mathbf{7 2 7 9 0 7 7}$ & $\mathbf{8 3 8 7 2 5 7}$ \\
\hline G. & $\begin{array}{l}\text { Population in } \\
\text { Million }\end{array}$ & $\mathbf{1 3 7 . 5 3}$ & $\mathbf{1 4 0 . 3 6}$ & $\mathbf{1 4 3 . 1 7}$ & $\mathbf{1 4 6 . 7 5}$ & $\mathbf{1 4 9 . 6 5}$ & $\mathbf{1 5 2 . 5 3}$ & $\mathbf{1 5 5 . 3 7}$ & $\mathbf{1 5 8 . 1 7}$ \\
\hline H. & $\begin{array}{l}\text { Per capita Income } \\
\text { (Rs.) }\end{array}$ & $\mathbf{2 5 5 5 1}$ & $\mathbf{2 7 5 6 3}$ & $\mathbf{2 9 1 2 5}$ & $\mathbf{3 1 9 3 3}$ & $\mathbf{3 5 9 1 7}$ & $\mathbf{4 1 0 2 2}$ & $\mathbf{4 6 8 5 0}$ & $\mathbf{5 3 0 2 7}$ \\
\hline
\end{tabular}

Source: http://www.statpak.gov.pk/depts/fbs/statistics/national_accounts/table12.pdf 
Table 3. Regional Aggregation 10 Regions of the Model

\begin{tabular}{|c|c|}
\hline Aggregated Regions & GTAP Region \\
\hline 1. Pakistan & Pakistan \\
\hline 2. India (IND) & India \\
\hline \multirow[t]{5}{*}{ 3. Rest of South Asia } & Bangladesh \\
\hline & Bhutan \\
\hline & Maldives \\
\hline & Nepal \\
\hline & Sri Lanka \\
\hline \multirow[t]{6}{*}{ 4. European Union } & United Kingdom \\
\hline & Germany \\
\hline & Denmark \\
\hline & Sweden \\
\hline & Finland \\
\hline & Rest of European Union \\
\hline \multicolumn{2}{|l|}{ 5. North American Free Trade Area } \\
\hline \multirow[t]{3}{*}{ NAFTA } & USA \\
\hline & Canada \\
\hline & Mexico \\
\hline 6. Association of South East Asian Nations & Indonesia \\
\hline \multirow[t]{4}{*}{ ASEAN-5 } & Malaysia \\
\hline & Philippines \\
\hline & Singapore \\
\hline & Thailand \\
\hline \multirow[t]{4}{*}{ 7. Rest of Asia } & Hong Kong \\
\hline & Korea \\
\hline & Taiwan \\
\hline & China \\
\hline 8. Japan (JPN) & Japan \\
\hline
\end{tabular}


Table 4. Commodity Aggregation: 10 Sector Model

\begin{tabular}{|c|c|}
\hline Aggregated Regions & GTAP Region \\
\hline 1. Agriculture Forestry & Paddy rice (pdr) \\
\hline \multirow[t]{11}{*}{ and Fisheries (AGRI) } & Wheat (wht) \\
\hline & Cereal grains nec(gro)(v_f) \\
\hline & Vegetable, Fruits, nuts \\
\hline & Oil seed (osd) \\
\hline & Sugar cane, sugar beet (c_b) \\
\hline & Plant based fibres (pfb) \\
\hline & Crops (nec) \\
\hline & Raw milk (rmk) \\
\hline & Wool (wol) \\
\hline & Forestry (for) \\
\hline & Fisheries (fis) \\
\hline \multirow[t]{4}{*}{ 2. Mining and Quarrying (MING) } & Coal (co) \\
\hline & Oil (ol) \\
\hline & Gas(gas) \\
\hline & Minerals (min) \\
\hline \multirow[t]{5}{*}{ 3. Proceed Food (PROF) } & Vegetable oil(voil) \\
\hline & Dairy products (mil) \\
\hline & Sugar cane (sgr) \\
\hline & Food products nec (ofd) \\
\hline & Beverages and tobacco products $\left(b_{-} \mathrm{t}\right)$ \\
\hline 4. Textile (TEXT) & Textile (tex) \\
\hline 5. Petroleum and Coal Products (PECP) & Petroleum and coal product $\left(\mathrm{p} \_\mathrm{c}\right)$ \\
\hline \multirow[t]{3}{*}{ 6. Services (SERC) } & Electricity (ely) \\
\hline & Gas, manufacture (gdt) \\
\hline & Water (wt) \\
\hline
\end{tabular}


Table 5. Experiment-1 15\% uniform Import Tariffs Estimated Welfare Trade Effect

\begin{tabular}{|l|l|l|l|l|l|l|l|l|l|}
\hline Region & EV-US\$Mil. & \%GDP & $\begin{array}{l}\text { Of } \\
\text { QGDP }\end{array}$ & TOT & $\begin{array}{l}\text { Volume } \\
\text { of } \\
\text { Exports }\end{array}$ & $\begin{array}{l}\text { Volume } \\
\text { of } \\
\text { Imports }\end{array}$ & $\begin{array}{l}\text { Of } \\
\text { Export } \\
\text { Price }\end{array}$ & $\begin{array}{l}\text { Import } \\
\text { Price }\end{array}$ & $\begin{array}{l}\text { DTBAL } \\
\text { US\$mil. }\end{array}$ \\
\hline ASEAN & 4.73 & 0.00 & 0.00 & 0.00 & 0.00 & 0.00 & 0.00 & 0.00 & 2.78 \\
\hline EU & -88 & 0.00 & 0.00 & 0.00 & 0.00 & 0.00 & 0.00 & 0.00 & 29.0 \\
\hline IND & -0.76 & 0.00 & $0 ., 00$ & 0.00 & 0.00 & 0.00 & 0.00 & 0.00 & 10.6 \\
\hline JPN & 12.7 & 0.00 & 0.00 & 0.00 & 0.00 & 0.00 & 0.00 & 0.00 & 18.0 \\
\hline PAK & $\mathbf{2 3 1 . 8 7}$ & $\mathbf{1 . 4 4}$ & $\mathbf{0 . 8 4}$ & $\mathbf{1 . 5 0}$ & $\mathbf{0 . 7 6}$ & $\mathbf{1 . 6 0}$ & $\mathbf{1 . 0 8}$ & $\mathbf{0 . 0 1}$ & $\mathbf{- 1 2 3 . 9 0}$ \\
\hline LKA & 13.67 & 0.00 & 0.00 & 0.00 & 0.00 & 0.00 & 0.00 & 0.00 & -6.90 \\
\hline MIE & 11.7 & 0.00 & 0.00 & 0.01 & 0.02 & 0.00 & 0.00 & 0.00 & -3.89 \\
\hline NAFTA & -33.20 & 0.00 & 0.00 & 0.00 & 0.00 & 0.00 & 0.00 & 0.00 & 29.90 \\
\hline ROW & -45.7 & 0.00 & 0.00 & 0.00 & 0.00 & 0.00 & 0.00 & 0.00 & 34.54 \\
\hline
\end{tabular}

Table 6. Experiment-1 15\% uniform Import Tariffs

Estimated Percentage Changes in Regional output in agricultural trade liberalization

\begin{tabular}{|c|c|c|c|c|c|c|c|c|}
\hline $\begin{array}{l}\text { SECTORS } \\
\text { (A)Industry } \\
\text { Out Put }\end{array}$ & ASEAN & $\mathbf{E U}$ & IND & JPN & PAK & LKA & NAFTA & ROW \\
\hline AGRI & -0.00 & 0.02 & 0.02 & 0.002 & -9.0 & 0.00 & 0.01 & 0.00 \\
\hline MINQ & -0.02 & 0.01 & 0.02 & 0.00 & -8.90 & 0.00 & 0.01 & 0.00 \\
\hline PROF & 0.02 & 0.01 & $0 . .01$ & 0.02 & -7.65 & 0.00 & 0.02 & 0.01 \\
\hline TEXT & -0.06 & 0.01 & 0.00 & 0.00 & -9.10 & 0.03 & 0.02 & 0.02 \\
\hline PECP & -0.12 & 0.02 & -0.10 & 0.00 & 30.2 & -0.09 & -0.07 & 0.06 \\
\hline MAEQ & 0.02 & 0.00 & 0.00 & 0.01 & -13.90 & 0.00 & 0.00 & 0.00 \\
\hline ОТНМ & 0.01 & 0.00 & 0.01 & 0.00 & -5.90 & 00 & 00 & 0.00 \\
\hline SERC & -0.00 & 0.00 & $-.0 .$. & 0.00 & 0.80 & 0.00 & -0.00 & 0.00 \\
\hline \multicolumn{9}{|l|}{$\begin{array}{l}\text { B-Aggregate } \\
\text { Exports }\end{array}$} \\
\hline AGRI & -0.00 & 0.02 & 0.02 & 0.002 & -8.90 & 0.00 & 0.01 & 0.00 \\
\hline MINQ & -0.02 & 0.01 & 0.02 & 0.00 & -8.54 & 0.00 & 0.01 & 0.00 \\
\hline PROF & 0.02 & 0.01 & $0 . .01$ & 0.02 & -17.90 & 0.00 & 0.02 & 0.01 \\
\hline TEXT & -0.06 & 0.01 & 0.00 & 0.00 & -6.78 & 0.03 & 0.02 & 0.02 \\
\hline РECP & -0.12 & 0.02 & -0.10 & 0.00 & 34.20 & -0.09 & -0.07 & 0.06 \\
\hline MAEQ & 0.02 & 0.00 & 0.00 & 0.01 & 13.8 & 0.00 & 0.00 & 0.00 \\
\hline ОТНМ & 0.01 & 0.00 & 0.01 & 0.00 & -11.75 & 00 & 00 & 0.00 \\
\hline SERC & -0.00 & 0.00 & $-.0 .$. & 0.00 & -15.0 & 0.00 & -0.00 & 0.00 \\
\hline
\end{tabular}


Table 7. 15\% Percent Uniform Percentage Changes in Regional Output and Trade

\begin{tabular}{|l|l|l|l|l|l|l|l|l|}
\hline $\begin{array}{l}\text { SECTORS } \\
\text { (A)Industry Out } \\
\text { Put }\end{array}$ & ASEAN & EU & IND & JPN & PAK & LKA & NAFTA & ROW \\
\hline AGRI & 0.00 & 0.00 & -.00 & 0.00 & $\mathbf{- 9 . 5 0}$ & -6.90 & -0.43 & -0.04 \\
\hline MINQ & -0.0 & 0.01 & 0.02 & 0.00 & $\mathbf{- 1 . 9 0}$ & 0.00 & 0.01 & -0.00 \\
\hline PROF & 0.02 & 0.01 & $0 . .01$ & 0.02 & $\mathbf{2 3 . 6 0}$ & 0.00 & 0.02 & -001 \\
\hline TEXT & -0.03 & 0.01 & 0.00 & 0.00 & $\mathbf{1 9 . 0}$ & 0.03 & 0.02 & -0.02 \\
\hline PECP & -0.01 & 0.02 & -0.10 & 0.00 & $\mathbf{2 0 . 0}$ & -0.09 & -0.07 & -0.06 \\
\hline MAEQ & 0.02 & 0.00 & 0.00 & 0.01 & $\mathbf{- 6 . 9 0}$ & 0.00 & 0.00 & -0.00 \\
\hline OTHM & 0.01 & 0.00 & 0.01 & 0.00 & $\mathbf{4 . 0}$ & 00 & 00 & -0.00 \\
\hline SERC & -0.00 & 0.00 & $-.0 .$. & 0.00 & $\mathbf{- 7 . 9 0}$ & 0.00 & -0.00 & -0.00 \\
\hline
\end{tabular}

Table 8. Combined Trade Policy SAFTA cum 15\% Uniform Import Tariffs Estimated Welfare and Trade Effects

\begin{tabular}{|l|l|l|l|l|l|l|l|l|l|}
\hline Region & $\begin{array}{l}\text { EV-US\$Mil. } \\
\text { Percentage } \\
\text { Changes }\end{array}$ & \%GDP & $\begin{array}{l}\text { Of } \\
\text { QGDP }\end{array}$ & TOT & $\begin{array}{l}\text { Volume } \\
\text { of } \\
\text { Exports }\end{array}$ & $\begin{array}{l}\text { Volume } \\
\text { of } \\
\text { Imports }\end{array}$ & $\begin{array}{l}\text { Of } \\
\text { Export } \\
\text { Price }\end{array}$ & $\begin{array}{l}\text { Import } \\
\text { Price }\end{array}$ & $\begin{array}{l}\text { DTBAL } \\
\text { US\$mil. }\end{array}$ \\
\hline ASEAN & -134.87 & -0.02 & 0.00 & 0.03 & -0.08 & -.0 .1 & 0.03 & -0.02 & 90.0 \\
\hline EU & -737 & 0.00 & 0.00 & 0.00 & 0.00 & 0.00 & 0.00 & 0.00 & 896.0 \\
\hline IND & -0.76 & 0.00 & $0 ., 00$ & 0.00 & 0.00 & 0.00 & 0.00 & 0.00 & 1098.00 \\
\hline JPN & 12.7 & 0.00 & 0.00 & 0.00 & 0.00 & 0.00 & 0.00 & 0.00 & 473.00 \\
\hline PAK & $\mathbf{5 6 6 . 9 0}$ & $\mathbf{4 . 4 5}$ & $\mathbf{0 . 8 9}$ & $\mathbf{6 . 8 9}$ & $\mathbf{- 0 . 4 4}$ & $\mathbf{9 . 8}$ & $\mathbf{7 . 8}$ & $\mathbf{0 . 2 9}$ & $\mathbf{- 3 6 7 . 9 0}$ \\
\hline LKA & -113.67 & 0.00 & 0.00 & 0.00 & 0.00 & 0.00 & 0.00 & 0.00 & 167.60 \\
\hline MIE & -511.7 & 0.00 & 0.00 & 0.01 & 0.02 & 0.00 & 0.00 & 0.00 & 234.80 \\
\hline NAFTA & -133.20 & 0.00 & 0.00 & 0.00 & 0.00 & 0.00 & 0.00 & 0.00 & 356.90 \\
\hline ROW & -109.9 & 0.00 & 0.00 & 0.00 & 0.00 & 0.00 & 0.00 & 0.00 & 4555.23 \\
\hline
\end{tabular}


Table 9. Sensivity Analysis Estimated Percentage Change in Pakistan's Output \& in Agriculture Trade Liberalization $15 \%$ Uniform Import Tariff $\quad$ SAFTA SAFTA cum 15\% Uniform Tariff

\begin{tabular}{|c|c|c|c|c|c|c|c|c|c|}
\hline & Central & $50 \%$ & $100 \%$ & Central & $50 \%$ & $100 \%$ & Central & $50 \%$ & $100 \%$ \\
\hline & Scenario & $\begin{array}{l}\text { Increase } \\
\text { In } \\
\text { ESUBM }\end{array}$ & $\begin{array}{l}\text { Increase } \\
\text { In } \\
\text { ESUBM }\end{array}$ & Scenario & $\begin{array}{l}\text { Increase } \\
\text { In } \\
\text { ESUBM }\end{array}$ & $\begin{array}{l}\text { Increase } \\
\text { In } \\
\text { ESUBM }\end{array}$ & Scenario & $\begin{array}{l}\text { Increase } \\
\text { In } \\
\text { ESUBM }\end{array}$ & $\begin{array}{l}\text { Increase } \\
\text { In } \\
\text { ESUBM }\end{array}$ \\
\hline $\begin{array}{l}\text { (a) } \\
\text { Industry } \\
\text { Output }\end{array}$ & & & & & & & & & \\
\hline AGRI & -0.98 & -1.33 & -1.89 & -3.1 & 3.88 & 5.66 & 2.45 & 3.39 & 5.66 \\
\hline MINQ & -8.56 & -8.89 & -13.01 & -8.98 & -12.40 & -18.88 & -16.93 & -23.04 & -34.90 \\
\hline PROF & $0-8.56$ & -7.78 & -8.67 & -2.56 & -3.44 & -14.36 & -18.88 & -9.45 & -8.56 \\
\hline TEXT & -6.76 & -6.67 & -7.78 & -2.56 & -3.62 & -7.90 & -10.0 & -12.4 & -14.8 \\
\hline PECP & 1.78 & 1.78 & 2.56 & 1.08 & -21.94 & -39.0 & 4.5 & -2.59 & -15.80 \\
\hline MAEQ & -16.97 & -23.66 & -28.6 & 4.45 & -2.56 & 4.7 & 4.7 & -2.33 & -13.5 \\
\hline TREQ & -17.08 & -19.75 & -21.0 & 81.6 & 131.6 & 207.6 & 50.7 & 81.3 & 120.4 \\
\hline
\end{tabular}

Table 10. Sensitivity Analysis, Estimated percentage change in Pakistan's output and Trade 15\% Uniform Import Tariff SAFTA SAFTA cum $15 \%$ Uniform Tariff (b) Aggregate Exports

\begin{tabular}{|c|c|c|c|c|c|c|c|c|c|}
\hline & Central & $50 \%$ & $100 \%$ & Central & $50 \%$ & $100 \%$ & Central & $50 \%$ & $100 \%$ \\
\hline & Scenario & $\begin{array}{l}\text { Increase } \\
\text { In } \\
\text { ESUBM }\end{array}$ & $\begin{array}{l}\text { Increase } \\
\text { In } \\
\text { ESUBM }\end{array}$ & Scenario & $\begin{array}{l}\text { Increase } \\
\text { In } \\
\text { ESUBM }\end{array}$ & $\begin{array}{l}\text { Increase } \\
\text { In } \\
\text { ESUBM }\end{array}$ & Scenario & $\begin{array}{l}\text { Increase } \\
\text { In } \\
\text { ESUBM }\end{array}$ & $\begin{array}{l}\text { Increase } \\
\text { In } \\
\text { ESUBM }\end{array}$ \\
\hline AGRI & -7.9 & -11.23 & -12.41 & 33.12 & -54.12 & 67.89 & 22.5 & 54.0 & 50.89 \\
\hline MINQ & -8.53 & -12.34 & -14.45 & -9.89 & -17.03 & -23.54 & -18.45 & -26.56 & -45.78 \\
\hline PROF & -17.45 & -23.56 & -28.97 & 8.89 & 25.27 & 71.4 & -5.78 & 2.56 & 29.63 \\
\hline TEXT & -6.79 & -10.78 & -14.67 & -14.78 & 23.44 & 27.05 & 6.4 & 12.43 & 16.67 \\
\hline PECP & 23.56 & 43.56 & 56.6 & -0.76 & -1.65 & -2.3 & 22.4 & 41.90 & 68.90 \\
\hline MAEQ & -17.09 & -27.78 & -34.6 & -26.78 & 70.1 & 12.50 & 56.9 & 67.2 & 43.8 \\
\hline TREQ & -18.9 & -27.8 & -34.7 & 65.6 & 67.9 & 78.6 & 52.6 & 71.0 & 65.0 \\
\hline
\end{tabular}

\section{(C) Aggregate Imports}

\begin{tabular}{|l|l|l|l|l|l|l|l|l|l|}
\hline AGRI & -7.89 & -9.8 & -6.78 & 32.7 & -49.0 & -71.0 & 20.9 & 37.9 & 58.7 \\
\hline MINQ & -1.56 & -3.78 & -3.54 & 2.34 & 6.54 & 8.76 & -.0 .67 & 2.89 & 6.43 \\
\hline PROF & 23.6 & 27.90 & 34.5 & 41.0 & 31.0 & 19.11 & 31.8 & 40.8 & 50.89 \\
\hline TEXT & 30.8 & 23.6 & 30.1 & -3.03 & -12.5 & -14.98 & 12.6 & 2.6 & 4.12 \\
\hline PECP & -5.18 & -7.56 & -8.67 & 0.78 & 0.88 & 0.65 & -4.78 & 8.8 & 11.3 \\
\hline MAEQ & 3.04 & 4.64 & 5.78 & 7.90 & 8.89 & 7.14 & 7.98 & 8.66 & 11.3 \\
\hline TREQ & 4.69 & 5.45 & 6.00 & 12.66 & 17.10 & 23.90 & 22.0 & 16.8 & 18.04 \\
\hline
\end{tabular}

